\title{
DISCURSIVE FUNCTIONS OF JAPANESE PERSONAL PRONOUNS
}

\author{
Etsuko Oishi \\ Tokyo University of Science \\ 1-3 Kagurazaka, Shinjuku-ku, 162-0825 Japan
}

\begin{abstract}
The first-person pronoun "I" refers to a particular individual as the speaker producing an utterance, and second-person "you" refers to another individual to whom the speaker directs the utterance. This well-accepted idea of personal pronouns, however, does not contribute to the explication of their functions in discourse although only first- and second-person pronouns refer to "discourse instances" (instances de discourse) (Benveniste 1966). This paper aims to establish the contention that the first-person pronoun "I" refers to the speaker as the addresser of an illocutionary act, and the second-person pronoun "you" refers to the hearer as the addressee of the illocutionary act. This clarifies the discursive function of the personal pronouns: they indicate participants of the illocutionary act performed in the discourse. Identifying the indicating function of personal pronouns makes it possible to analyze Japanese personal pronouns and the formality level of the discourse, which are generally assumed to be a problem case, in a consistent manner.
\end{abstract}

Keywords: discourse, personal pronouns, Japanese, speech acts, J.L. Austin

\section{KAPLAN'S THEORY OF INDEXICALS}

According to Kaplan (1989: 489), personal pronouns are indexicals along with demonstrative pronouns such as "that" and "this", adverbs such as "here", "now", and "tomorrow", and adjectives such as "actual" and "present". Among these indexicals Kaplan identifies two types, true demonstratives ("he", "she", "that", etc.) and pure indexicals ("I", "here", "now", etc.). A referent of true demonstratives is fixed by the speaker's demonstrations or intentions, whereas a referent of pure indexicals does not depend on such demonstrations or intentions. For example, the character of "I" determines the content of each of its tokens to be the speaker producing it, where a contextual factor is sufficient to determine the content.

This idea is questioned by Sidelle (1991), who introduces the Answering Machine Paradox. Since the character of "I", "here" and "now" is a function from a contextual parameter to the referent of the expression, utterances of "I", "here" and "now" refer, respectively, to the utterer, the location of utterance and the time of utterance. Since the sentence "I am not here now" is uttered truly if and only if the utterer is not at the location of utterance at the time of utterance, the sentence "I am not here now" may never be uttered truly; an utterer is always at the location of utterance at the time of utterance. This conclusion is at odds with the intuition that there are true instances of the sentence "I am not here now" when it is uttered on a telephone answering machine - hence the Answering Machine Paradox - and written on a post-it note and stuck on an office door when its inhabitant is not in residence. 
Corazza et al. (2001) presents another problem. Imagine Joe is not in his office one day and Ben notices that a number of students keep approaching his door and knocking. They then stand around and look bemused for a while before leaving. Taking pity on these poor students wasting their time, Ben decides to attach his "I am not here today" note to Joe's door. The trick works; the students, instead of knocking and waiting, take one look at the note and then leave. What does "I" refer to? Corazza et al. (2002) claim, at the moment a student looks at the note, it would be strange to deny that it refers to Joe.

The present paper makes the contention that Japanese personal pronouns exhibit another problem. There are several forms of first-person pronouns in Japanese, and they are differentiated by gender and the formality level of speech. Shibatani (1990: 371) describes five first-person pronouns. Watakushi, watashi, boku and ore (ordered from the most formal to the least formal) are used by male speakers. Watakushi, watashi and atashi (ordered from the most formal to the least formal) are used by female speakers ${ }^{1}$. As Kaplan explains, the character of these first-person pronouns determines the content of each of their tokens to be the speaker producing it. It is, however, puzzling why there are several first-personal pronouns that can refer to the same speaker. This strongly suggests that the function of the Japanese first-person pronouns is more than selecting a particular speaker as the content of each of their tokens. In the rest of the present paper, a theory of personal pronouns that replaces Kaplan's will be introduced and, accordingly, the discursive functions of personal pronouns will be described.

\section{DISCURSIVE FUNCTIONS OF PERSONAL PRONOUNS}

Personal pronouns are deictic expressions, and distinguished in terms of the referent's roles in discourse, as the speaker, the hearer and the third person (Lyons 1977, Gardelle \& Sorlin 2015). Benveniste (1966) shows that only first- and second-person pronouns refer to "discourse instances" (instances de discourse). The present section describes discursive functions of first- and second-person pronouns. First, terminologies used in speech act theory are introduced.

Austin ([1962] 1975: 14 - 15) distinguishes a certain person in certain circumstances who utters certain words to bring about a certain conventional effect, that is, an illocutionary effect (described in felicity condition [A.1]) from a person in a given case (described in felicity condition [A.2)]. Given below are Austin's felicity conditions:

(A.1) There must exist an accepted conventional procedure having a certain conventional effect, that procedure to include the uttering of certain words by certain persons in certain circumstances, and further,

(A.2) the particular persons and circumstances in a given case must be appropriate for the invocation of the particular procedure invoked.

(B.1) The procedure must be executed by all participants both correctly and

(B.2) completely.

1 Shibatani (1990: 371) describes four second-person pronouns in Japanese: anata, kimi, anta and omae (ordered from the most formal to the least formal) used by male speakers; anata and anta are used by female speakers, and anata is more formal than anta. 
(Г.1) Where, as often, the procedure is designed for use by persons having certain thoughts or feelings, or for the inauguration of certain consequential conduct on the part of any participant, then a person participating in and so invoking the procedure must in fact have those thoughts or feelings, and the participants must intend so to conduct themselves, and further

(Г.2) must actually so conduct themselves subsequently.

(Austin 1975: 14-15)

Using Austin's examples of explicit performatives, let us explain the distinction between (i) a certain person who brings about an illocutionary effect and (ii) a person in a given case:

(E. a) 'I do (sc. Take this woman to be my lawful wedded wife)' — as uttered in the course of the marriage ceremony.

(E. b) 'I name this ship the Queen Elizabeth' — as uttered when smashing the bottle against the stem.

(E. c) 'I give and bequeath my watch to my brother' - as occurring in a will.

(E. $d$ ) 'I bet you sixpence it will rain tomorrow.'

(Austin 1975: 5)

The first-person pronoun "I" in these examples does not only refer to a speaker in a given case, but also indicates the performer who brings about the illocutionary effect of vowing, naming, bequeathing, or betting. We refer to a speaker in a given case as a speaker and to the performer of an illocutionary act as the addresser. In the case of explicit performatives, a speaker in a given case explicitly refers, by the first-person pronoun "I", to her/himself as the addresser of a particular illocutionary act: the pronoun "I" refers to the speaker and indicates the addresser of the illocutionary act.

Similar duality exists in the second-person pronoun "you". A conventional illocutionary effect is brought about on a certain person, that is, the target recipient of an illocutionary act. We call this person the addressee of the illocutionary act, who is distinguished from a hearer in a given case, to whom the speaker speaks. Consider the following examples:

(1) I welcome you.

(2) I apologize to you.

(3) I appoint you to the Chief Justice of the Supreme Court.

(4) I object to you.

Using the second pronoun "you", a speaker in each of these cases refers to the hearer to whom s/he speaks, as the target recipient of the illocutionary act of welcoming, apologizing, appointing or objecting; "you" indicates the target recipient of the illocutionary act, as well as referring to the hearer in the case.

Austin's speech act theory reveals complicated discursive situations ("discourse instances" in Benveniste's term). An individual is referred to by first person pronoun "I" not only in terms of her/his discursive role of saying something to someone to express her/himself, but also in terms of her/his discursive role of the addresser of a particular illocutionary act. A hearer is referred to by the second-person pronoun "you" not only 
in terms of her/his discursive role of being spoken to by the speaker, but also in terms of her/his discursive role of the addressee of a particular illocutionary act. A speaker in a given case, that is, in a given discourse, performs a particular illocutionary act as the addresser, while identifying the hearer as the addressee of the act ${ }^{2}$. This is illustrated in the following diagram.

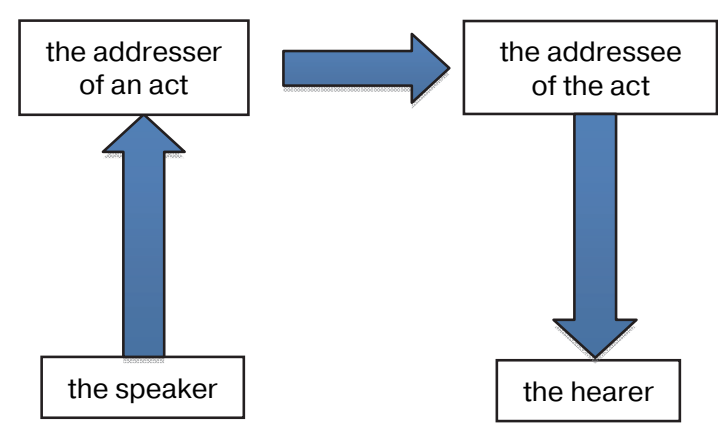

Diagram 1: the model of the illocutionary act

Goffman (1981: 144) also distinguishes different discursive functions of the speaker, which he describes as animator, author and principal. An animator is "a body engaged in acoustic activity" or "an individual active in the role of utterance production". An author "has selected the sentiments to be expressed and the words in which they are encoded". A principal is "someone whose position is established by the words that are spoken, someone whose beliefs have been told, someone who is committed to what the words say".

There are some similarities between Goffman's and Austin's ideas. Goffman's concept of animator corresponds to the speaker performing a locutionary act in Austin (1975: 92 - 93): it is an act of saying something, which is composed of (i) the phonetic act of uttering certain noises, (ii) the phatic act of uttering certain vocables or words and (iii) the rhetic act of using that pheme (in the phatic act) or its constituents with a certain more or less definite sense and reference. Goffman's concept of author corresponds to the speaker in a given discourse performing an illocutionary act, and Goffman's concept of principal corresponds to the addresser of an illocutionary act. Goffman's triadic distinctions of the speaker and their correspondence to the speech-act-theoretic model are illustrated in Diagram 2:

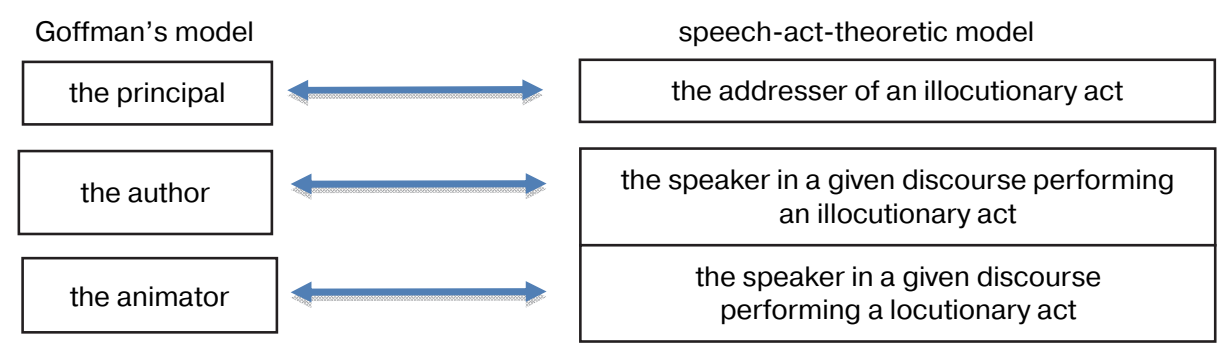

Diagram 2: Goffman's triadic distinctions of the speaker

${ }^{2}$ See Oishi and Fetzer (2016) and Oishi (2014). 
The animator, the author and the principal of an utterance are all referred to or indicated by the first-person pronoun. Since it has been shown that both the speaker and the addresser, who correspond to the author and the principal in Goffman (1981), are referred to or indicated by the first-person pronoun, let us show the animator is referred to by it:

(5) (a knock on the door)

A: Who is it?

B: It's me.

The first person pronoun "me" refers to the individual active in the role of this utterance production, and speaker A identifies who speaker B is by means of the characteristics of the speaker as an animator, that is, the acoustic features of the utterance.

In addition to these distinct concepts of participants of the discourse, an individual who belongs to the world that is spoken about is referred to by first- and second-person pronouns. Goffman calls such an individual a figure.

... as speaker, we represent ourselves through the offices of a personal pronoun, typically, "I," and it is thus a figure - a figure in a statement - that serves as the agent, a protagonist in a described scene, a "character" in an anecdote, someone, after all, who belongs to the world that is spoken about, not the world in which the speaking occurs (Goffman 1981: 147) (the emphases are Goffman's).

The identification of these different concepts of discursive participants and figures in the world that is spoken about allows us to clarify the confusions which are caused by different uses of the first-person pronoun "I" and the second-person pronoun "you". This is the target of the following section.

\section{THE ANSWERING MACHINE PARADOX AND THE "I AM NOT HERE TODAY" NOTE}

Sidelle (1991) claims that, according to Kaplan's theory, the sentence "I am not here now" may never be uttered truly because an utterer is always at the location of utterance at the time of utterance. This is in conflict with our intuition that the sentence can be uttered truly as an answering machine message.

As we argued in the proceeding section, the first-person pronoun "I" refers to the speaker (as the animator and the author of an utterance) and indicates the addresser of an illocutionary act (the principal of an utterance), and, as Goffman (1981) observes, the pronoun can also refer to the speaker as a figure in the world that is spoken about. "I" in the sentence "I am not here now" refers to (i) the speaker performing a locutionary act, or the animator who produced the utterance and (ii) the speaker performing an illocutionary act, or the author who has selected the sentiments to be expressed by the sentence "I am not here now", and indicates (iii) the addresser of the act of informing, more specifically, the addresser informing the addressee about someone's whereabouts, or the principal who is committed to the truth of affirming someone's whereabouts. "I" also refers to the speaker as a figure in the world about whom the addresser has per- 
formed the illocutionary act of informing, or a figure in the world that the principal affirms about (and s/he is committed to its truth). This is shown in the following diagram:

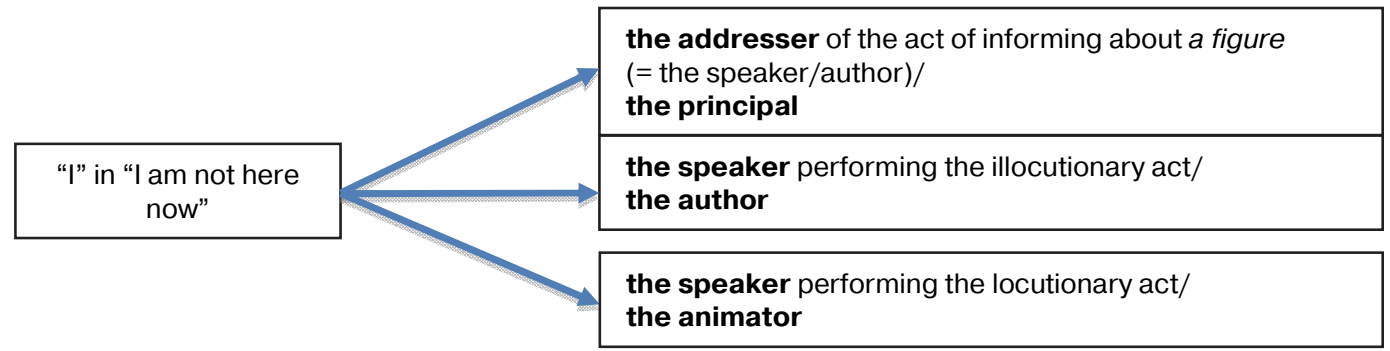

Diagram 3: "I am not here now"

Because the illocutionary act that the speaker performs is the recorded act, the speaker as a figure can be away from the place of utterance, which makes the utterance true ${ }^{3}$.

The problem that Corazza et al. (2002) pose is a little more complicated. Since the "I am not here today" note is written by Ben, Ben is the writer performing the locutionary act, or the animator who wrote the note. However, Ben does not do this on his own authority, but for the sake of Joe: Ben does what Joe would have done if he had known that his students would keep visiting his office and wasting their time. Therefore, the speaker performing the illocutionary act, or the author, who is referred to by "I", is Joe, not Ben. Just as the utterance of "I am not here now" on the answering machine, "I" in "I am not here today" indicates the addresser of the act of informing, or the principal who is committed to the truth of affirming about someone's whereabouts. "I" also refers to the speaker as a figure in the world about whom the addresser has performed the illocutionary act of informing, or a figure in the world about whom the principal affirms (and $\mathrm{s} /$ he is committed to its truth). This is shown in the following diagram:

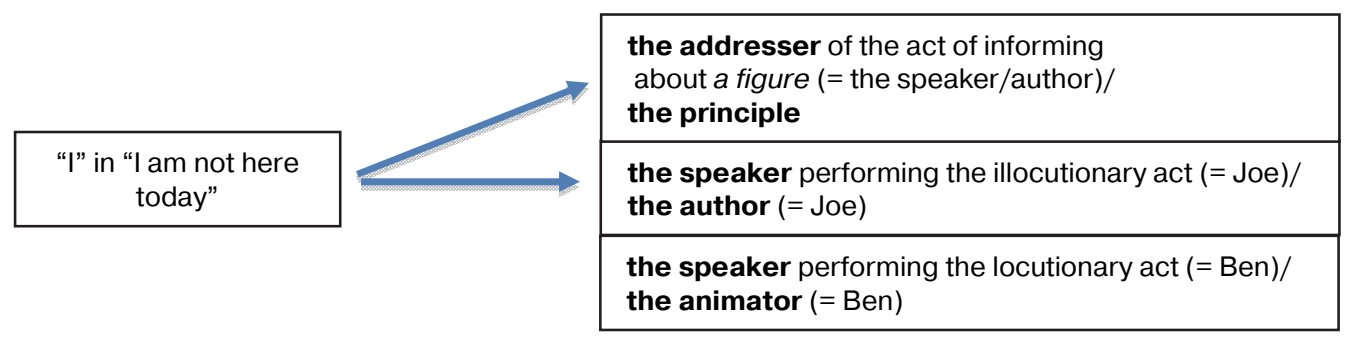

Diagram 4: "I am not here today"

Kaplan (1989) characterizes the referent of a token of "I" as the speaker who produces it, where the term "the speaker" is used somewhat loosely. The speaker who performs an illocutionary act, or the author, is not distinguished from the speaker as a figure,

${ }^{3}$ Sidelle (1991) reaches a similar conclusion by claiming that an utterance can be deferred: the utterance takes place when the message is heard by the hearer or read by the reader (the decoding time) not when it is recorded or written (the encoding time). 
about whom the illocutionary act is performed. Sidelle (1991) identifies this problem as the Answering Machine Paradox. The speaker who performs an illocutionary act, or the author, is not distinguished from the speaker who is performing a locutionary act, or the animator, either. This is pointed out by Corazza et al. (2002). Furthermore, the addresser of a particular illocutionary act who is indicated by "I" is not included in Kaplan's theory. The analysis of the addresser of an illocutionary act, however, cannot be replaced by that of the speaker who performs an illocutionary act, or the author. To prove this point, Nunberg's (1993) analysis of first- and second-person pronouns will be examined in the following section.

\section{PERSONAL PRONOUNS AND PROPER NAMES}

Nunberg (1993: 20-21) claims that "I" and singular "you" can contribute properties in utterances that express general propositions. Consider the following examples:

(6) Condemned prisoner: I am traditionally allowed to order whatever I like for my last meal.

(7) President: The Founders invested me with sole responsibility for appointing Supreme Court justices.

(8) Chess teacher giving an introductory lesson to a student who has just played $4 . N \times P$...: According to all the textbooks, you often get in trouble with that move.

These utterances allow the general readings: "I", "me" and "you" do not only refer to a particular speaker or hearer, but generally to the condemned prisoner, the president, and the person who plays 4 x P..., respectively. These general readings are, however, not available when a name or referentially used description is put in the place of the indexical, as the following examples show:

(9) Darnay (the prisoner currently in cell 15) is traditionally allowed to order whatever he likes for his last meal.

(10) The Founders invested George Bush (the man who ordered the invasion of Panama) with sole responsibility for appointing Supreme Court justices.

(11) According to all the textbooks, Bill (my neighbor) often gets in trouble with that move.

Let us re-analyze these examples on the basis of the model of first- and second-person pronouns we have proposed.

In uttering "I am traditionally allowed to order whatever I like for my last meal" (in [6]), the speaker performs an illocutionary act of an exercitive type (Austin 1975: 155-57). By the first-person pronoun "I", the speaker refers to her/himself as the addresser of exercising her/his rights, who is, according to Austin's (1975: 14) felicity condition (A.1), a condemned prisoner who has the rights to order whatever s/he likes for her/his last meal. In this use, "I" both refers to the speaker and indicates the addresser of the illocutionary act. "Darnay" (the prisoner currently in cell 15) in the utterance "Darnay ... is traditionally allowed to order whatever he likes for his last meal" (in [9]), on the other hand, refers only to a figure in the world whose rights as a condemned prisoner are affirmed. Obviously, "Darnay" does not indicate the addresser of the act of affirming the condemned prisoner's rights, which is an expositive illocutionary act 
type (Austin 1975: 161 - 63). The name "Darnay" does not indicate the addresser of exercising her/his rights as a condemned prisoner (as "I" in the utterance [6]), either. This is illustrated by the following diagram:

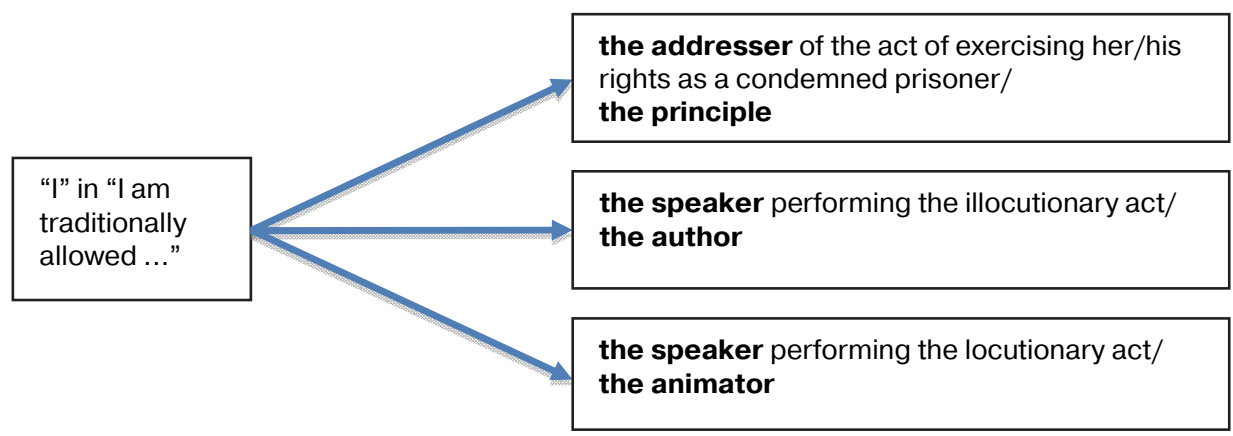

Diagram 5: "I am traditionally allowed to order whatever I like for my last meal”

\begin{tabular}{|l|l|}
\hline $\begin{array}{l}\text { the addresser of the act of affirming/ } \\
\text { the principle }\end{array}$ \\
$\begin{array}{l}\text { "Darnay" in "Darnay } \\
\text { is traditionally al- } \\
\text { lowed ..." }\end{array}$ & $\begin{array}{l}\text { a figure whose rights the addresser performs the illocu- } \\
\text { tionary act of affirming about }\end{array}$ \\
\hline $\begin{array}{l}\text { the speaker performing the illocutionary act/ } \\
\text { the author }\end{array}$ \\
$\begin{array}{l}\text { the speaker performing the locutionary act/ } \\
\text { the animator }\end{array}$ \\
\hline
\end{tabular}

Diagram 6: "Darnay is traditionally allowed to order whatever he likes for his last meal"

The same is true with the second-person pronoun "you". In uttering "According to all the textbooks, you often get in trouble with that move" (in [8]), the speaker refers, by "you", to the hearer in this discourse as the addressee of the exercitive illocutionary act of warning: according to the felicity condition (A.1), a less knowledgeable chess player who is making a bad move. When "you" is replaced by name "Bill", it refers only to a figure in the world whose chess move is described as a bad move. The name does not indicate the addressee of the illocutionary act of warning or describing. Let us show this in diagram 7 and 8.

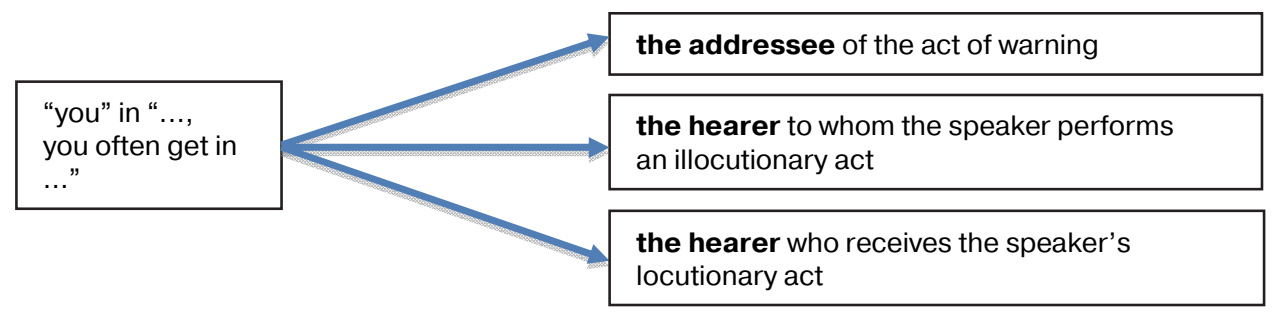

Diagram 7: "According to all the textbooks, you often get in trouble with that move" 


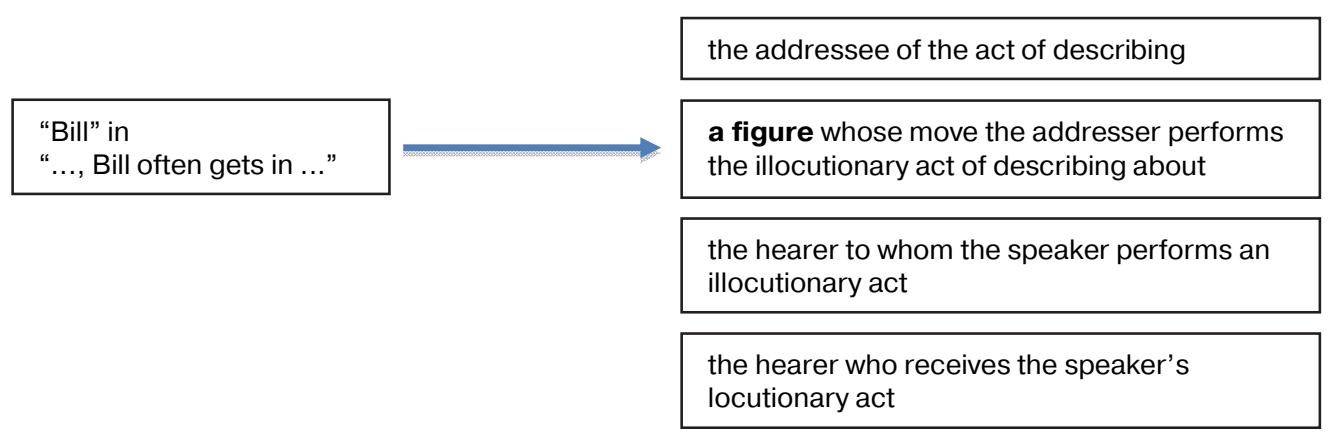

Diagram 8: "According to all the textbooks,

Bill often gets in trouble with that move"

Nunberg (1993: 20 - 21) says that "I", "me", and "you" in utterances (6) to (8) contribute properties in utterances that express general propositions. This is because "I" in utterance (6) indicates the addresser of the illocutionary act of exercising, that is, a condemned prisoner who asserts the right of ordering whatever s/he likes for her/his last meal, and other speakers in an equivalent situation can be the addresser of this type of illocutionary act. "You" in utterance (8) indicates the addressee of the act of warning, that is, a less knowledgeable chess player whose move is warned about, and other hearers in an equivalent situation can be the addressee of this type of illocutionary act. Unlike the first- and second-person pronouns "I", "me", and "you", the names in the examples (9) to (11) do not have the discursive function of indicating the addresser or addressee of an illocutionary act.

So far we have described the double discursive function of first- and second-person pronouns: the function of referring to a speaker or hearer in a given case, and indicating the addresser or addressee of an illocutionary act. There is, however, a specific case in which the addressee of an illocutionary act is indicated by the second-person pronoun "you" without a hearer being referred to by it. Consider the following example:

(12) You're - I don't mean you personally - you're going to destroy us all in a nuclear war (Kitagawa \& Lehrer 1990: 743).

A European woman utters this to one of the authors talking about American political and military policy in Europe. Kitagawa \& Lehrer (1990: 743) analyze the utterance as follows: "In this utterance, the referents of (italicized) you are not specified in a way whereby the hearer could pick out the individuals. Yet, you here could not be replaced by one as in the case of impersonal pronouns...".

To analyze this utterance, let us first add numbers to the token of "you":

(13) You $_{1}$ 're - I don't mean you 2 personally — you 3 're going to destroy us all in a nuclear war.

"You," refers to the hearer in this discourse and indicates the addressee of an illocutionary act. "You" ${ }_{2}$ refers only to the hearer ("...you 2 personally"), which suggests "you," only indicates the addressee of the illocutionary act. Accordingly, "you,", which is the repeated utterance of "you,", indicates the addressee of the behabitive illocu- 
tionary act of criticizing (Austin 1975: 160 - 61): a person who is being criticized for support for American political and military policy in Europe. This is shown in the following diagram:

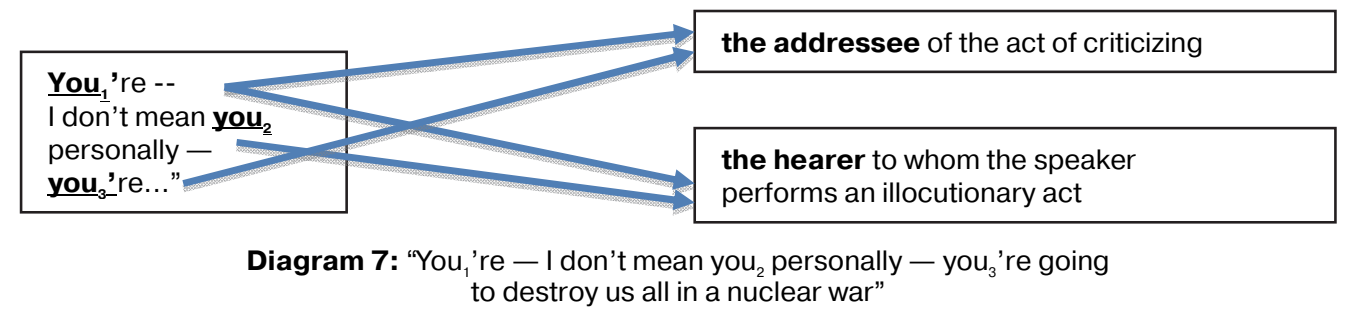

In this example, the addressee of the illocutionary act of criticizing is explicitly indicated by the phrase "I don't mean you personally", which is a hedge (Brown \& Levinson 1987: 164) or metacommunication comment (Fetzer 2013: 699). This, in turn, serves as evidence for the double function of the second-person pronoun "you". The speaker is aware that "you" indicates the addressee of the illocutionary act of criticizing as well as referring to the hearer in this discourse, and finds it necessary to indicate explicitly the addressee without referring to the hearer (and does so by using the hedge or metacommunication comment of "I don't mean you personally").

\section{PERSONAL PRONOUNS IN JAPANESE}

The arguments in the preceding sections strongly suggest that we need a pragmatic theory in which (i) the referents of personal pronouns "I" and "you" are distinguished in more fine-grained ways than Kaplan's (1989), and (ii) the discursive functions of these pronouns are described fully.

What discursive functions are marked by different forms of first- and second-person pronouns of languages like Japanese?

Personal pronouns are found in most, if not all, languages. Goddard and Wierzbicka (1994: 37) claim that "I" and "you" are universal semantic primitives which are attested as distinct lexical elements in every human language known to date. According to Gardelle \& Sorlin (2015: 5), Japanese personal pronouns exhibit a problem case to universality of personal pronouns:

Whether absolute universality can actually be claimed is a matter of some debate, due to problem cases in Southeast Asian languages such as Burmese, Thai or Japanese, in which 'pronouns' are derived from nominal forms (Bhat 2004: 30). For instance, in Burmese, the first-person pronouns are derived from the noun cun 'slave' [...], while second-person pronouns are derived from religious titles (Bradley 1993: 158). In Japanese, 'personal pronouns' are obtained from nouns of occupation or status titles, and have different forms depending on sex, age, social status or emotional correlation [...]. Some studies, however (e.g. Hinds 1986: 241; Diller 1994), find that these forms also show some characteristics which set them apart from basic nominals.

Some linguists analyze Japanese personal pronouns broadly including the use of nouns of occupations or status (Suzuki 1973; Kuroda 1965) on which Gardelle \& Sorlin's (2015) description of Japanese personal pronouns seems to be based. Let us, however, analyze more straightforward personal pronouns in Japanese. 
Watakushi, watashi, atashi, boku and ore are first-person pronouns. Watakushi means a person (in contrast to a figure who belongs to the public sphere of the world ${ }^{4}$ ), and is used as a first-person pronoun, and watashi and atashi are colloquial forms of watakushi, and atashi is used by female speakers. The Chinese character which is pronounced as boku now was pronounced as yatsukare/yatsugare, which was a humble first-person pronoun in old times ${ }^{5}$, but, since the Meiji era (1868 to 1912), boku has been generally used as a first-person pronoun for male speakers. Ore is a self-referring form of a speaker when the hearer is socially equal to, or lower than the speaker. It was used by both male and female speakers, but, since the Azuchi Momoyama era (1568 to 1598), it has been used as a first-person pronoun for male speakers ${ }^{6}$.

The first-person pronouns for male speakers, watakushi, watashi, boku and ore are ordered from the most formal to the least formal (Shibatani 1990: 371) on the basis of the understandings that (i) colloquial forms are less formal than non-colloquial forms, and (ii) a speaker uses a less formal form when s/he addresses a hearer who is socially equal to, or lower than, her/him. The first-person pronouns for female speakers, wata$k u s h i$, watashi and atashi are ordered from the most formal to the least formal on the same understandings.

Anata, kimi, anta and omae are second-person pronouns. Anata originally means a place which is physically or temporally far away, or a person in that place, and it has been used as an honorific form of the second-person pronoun since the Edo era (1603 to 1867). Anta is a colloquial form of anata. Kimi is used as a less formal form of the second-person pronoun. It was used by both male and female speakers until the Heian era (794 to 1192), but it is now used by male speakers. Omae was used as an honorific form of a second-person pronoun, but the word lost the function as an honorific, and since the Meiji era, it has been used when a speaker addresses a hearer who is socially equal to, or lower than, the speaker ${ }^{7}$.

The second-person pronouns for male speakers, anata, kimi, anta and omae are ordered from the most formal to the least formal (Shibatani 1990: 371) according to the understandings of formality explained above ${ }^{8}$. Anata and anta are used by female speakers, and anata is more formal than anta because the latter is a colloquial form of the former.

Why do these different forms of the first- and second-person pronouns exist? The differences among these forms do not contribute at all to selecting a particular speaker because of the function of the speaker as an animator. They hardly contribute to selecting a particular hearer because nonverbal communicative tools such as eye-gaze and posture work more efficiently. These differences rather show different social relationships between a speaker and a hearer in a given discourse. By using a particular first-person pronoun, the Japanese speaker indicates the speaker's social status (or stance) vis-à-vis the hearer in the discourse. Similarly using a particular second-person pronoun, the Japa-

\footnotetext{
${ }^{4}$ Iwanami Kogo Jiten (Iwanami Old-Japanese Dictionary).

5 Yatsukare was used in Nihon Shoki (the Chronicle of Japan), published in 720.

${ }^{6}$ Iwanami Kogo Jiten (Iwanami Old-Japanese Dictionary) and Super Dai Jirin, which is a Japanese dictionary.

${ }^{7}$ Iwanami Kogo Jiten (Iwanami Old-Japanese Dictionary) and Super Dai Jirin.

8 The above mentioned dictionaries do not specify omae as a second-person pronoun for male speakers, but omae seems to be used predominantly by male speakers.
} 
nese speaker indicates the social status of the hearer vis-à-vis the speaker in the discourse. In other words, Japanese personal pronouns do not only refer to discourse participants in terms of their discursive role as a speaker or hearer, but also mark an extra characterization of social statuses of the discourse participants.

For example, in addition to referring to the speaker (animator and author) and indicating the addresser of a particular illocutionary act (principle), the first-person pronoun ore indicates the social status (or stance) of a male person: he is communicating with a hearer who is socially equal to, or lower than him. As well as referring to the hearer and indicating the addressee of an illocutionary act, the second-person pronoun anata indicates the hearer's social status: her/his social status is such that s/he should be communicated with respect. This is illustrated in the following diagram:

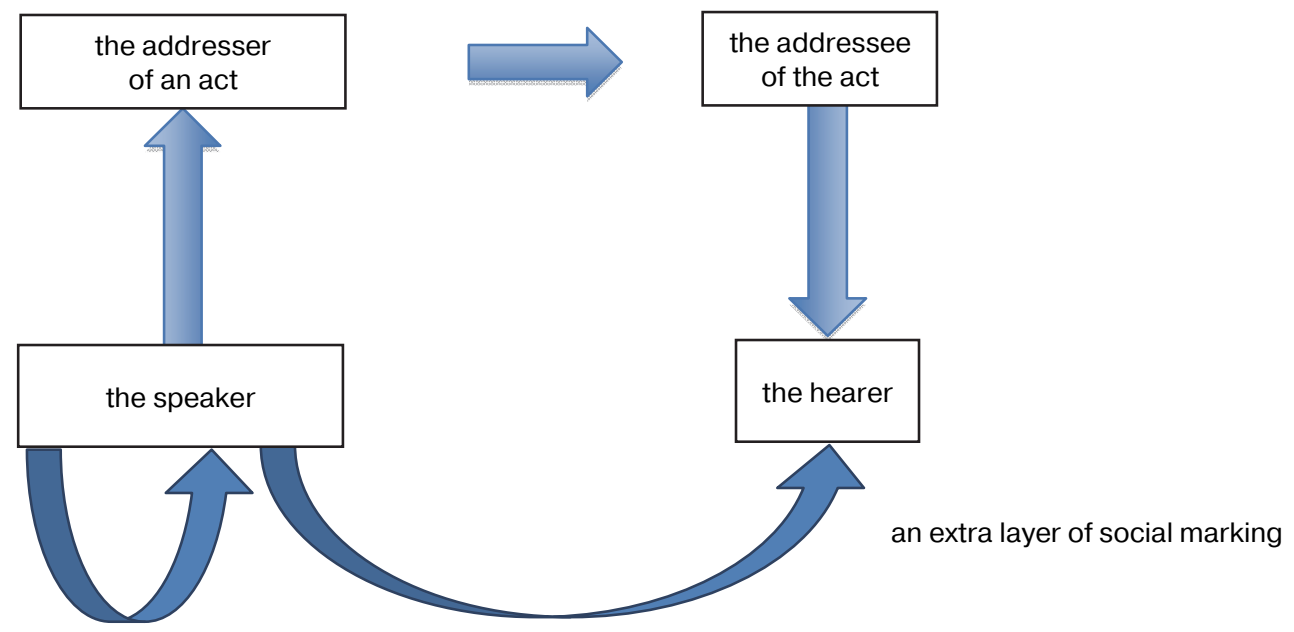

Diagram 8: social marking made by Japanese personal pronouns

Let us examine one example. Sinichi Tsutsumi, who became an actor after working as a stagehand, refers to his past utterance "Ore omoteni detaku nainya", 10 (I do not want to be on the stage) to perform the illocutionary act of protesting, which is a behabitive type (Austin 1975: 160-161). This utterance can be analyzed in the following way:

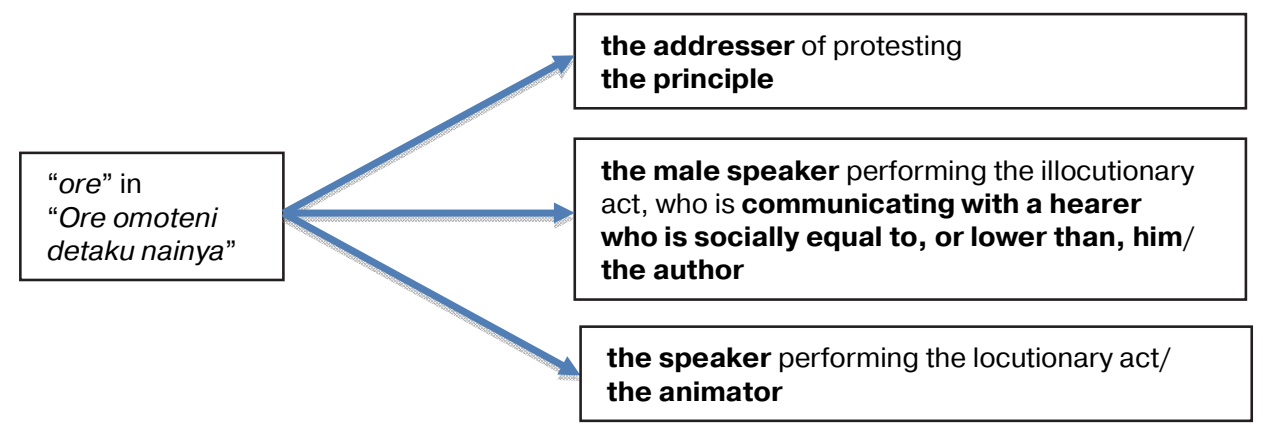

Diagram 9: "Ore omoteni detaku nainya" (I do not want to be on the stage)

9 "Nainya" is a regional-dialect form of "nainda".

${ }^{10} \mathrm{http}: / /$ eiga.com/movie/77297/interview/. 
As "ore" in "Ore omoteni detaku nainya" exemplifies, Japanese first-person pronouns do not only refer to an individual in a given discourse neutrally as the speaker performing a particular illocutionary act: they specify the speaker in terms of her/his social status vis-à-vis the hearer to whom s/he speak. Similarly, Japanese second-person pronouns does not refer neutrally to the hearer to whom a speaker speaks in a given discourse, but specifies her/him in terms of her/his social status vis-à-vis the speaker.

\section{THE CONCLUSION}

On the basis of Austin's speech act theory, the present paper models discursive situations by describing functions of personal pronouns. An individual is referred to by the first person pronoun "I" not only in terms of her/his discursive role of saying something to someone to express her/himself, but also in terms of her/his discursive role of the addresser of a particular illocutionary act. A hearer is referred to by the second-person pronoun "you" not only in terms of her/his discursive role of being spoken to by a speaker, but also in terms of her/his discursive role of the addressee of a particular illocutionary act.

Japanese personal pronouns reveal another way of characterizing an individual in discourse: social characterization of her/him vis-à-vis the hearer who s/he speaks to, or the speaker who speaks to her/him. By using a particular first-person pronoun, an individual is indicated as a speaker communicating with a hearer informally, or as a speaker who is communicating with a hearer who is socially equal to, or lower than, the speaker. An individual can be indicated as a male or female speaker. Similarly, using a particular second-person pronoun, an individual is indicated as a hearer with whom the speaker is communicating with respect, or as a hearer who is socially equal to, or higher than the speaker.

These descriptions of personal pronouns demonstrate how discourse participants refer to themselves or hearers by personal pronouns, and explicitly perform an illocutionary act by indicating themselves and hearers as the addresser and addressee of the act, respectively. In addition, Japanese speakers develop a discourse of a particular social type by indicating the social relationship between them and hearers, or the formality level of their communication.

(C) Etsuko Oishi, 2017

\section{REFERENCES}

Austin, J.L. ([1962] 1975) How to Do Things with Words. Oxford: Oxford University Press.

Benveniste, E. (1966) Problèmes de linguistique générale. Volume 1, Paris: Gallimard.

Bhat, D.N.S. (2004) Pronouns. Oxford: Oxford University Press.

Bradley, D. (1993) Pronouns in Burmese-Lolo. Linguistics of the Tibeto-Burmean Area 16(1), $157-215$.

Brown, P., Levinson, S. (1987) Politeness: Some Universals in Language Usage. Cambridge: Cambridge University Press.

Corazza, E., Fish, W., Gorvett, J. (2002) Who is I? Philosophical Studies 107, 1-21.

Diller, A. (1994) Thai. In: Goddard, C., Wierzbicka, A. (eds.) Semantic and Lexical Universals: Theory and Empirical Findings. Amsterdam: John Benjamins, 149-170.

Fetzer, A. (2013) The structuring of discourse. In: Sbisà, M., Turner, K. (eds.) Handbooks of Pragmatics: Volume 2 Pragmatics of Speech Actions. Berlin: De Gruyter Mouton, 685-711. 
Gardelle, L., Sorlin, S. (2015) Personal pronouns: an exposition. In: Gardelle L., Sandrine, S. (eds.), The Pragmatics of Personal Pronouns. Amsterdam: John Benjamins, 1-23.

Goddard, C., Wierzbicka, A. (1994) Semantic and Lexical Universals: Theory and Empirical Findings. Amsterdam: John Benjamins.

Goffman, E. (1981) Forms of Talk. Philadelphia: University of Pennsylvania Press.

Hinds, J. (1986) Japanese. London: Croom Helm.

Kaplan, D. (1989) Demonstratives: an essay on the semantics, logic, metaphysics, and epistemology of demonstratives and other indexicals. In: Almog, J., Perry, J., Wettstein, H. (eds.), Themes from Kaplan. Oxford: Oxford University Press, 481-563.

Kitagawa, C., Lehrer, A. (1990) Impersonal uses of personal pronouns. Journal of Pragmatics 14, 739-759.

Kuroda, S. (1965) Generative Grammatical Studies in the Japanese Language. Ph.D. Dissertation, M.I.T.

Lyons, J. (1977) Semantics, Vols. 1 and 2. Cambridge: Cambridge University Press.

Nunberg, G. (1993) Indexicality and deixis. Linguistics and Philosophy 16, 1- 43.

Oishi, E. (2014) Evidentials in entextualization. Intercultural Pragmatics 11, 437-462.

Oishi, E., Fetzer, A. (2016) Expositives in discourse. Journal of Pragmatics 96, 49—59.

Shibatani, M. (1990) The Languages of Japan. Cambridge: Cambridge University Press.

Sidelle, A. (1991) The answering machine paradox. Canadian Journal of Philosophy 21, 525-539.

Suzuki, T. (1973) Kotoba to Bunka (Language and Culture). Tokyo: Iwanami.

\section{Article history:}

Received: 30 January 2017

Revised: 28 February 2017

Accepted: 01 March 2017

\section{For citation:}

Oishi, E. (2017). Discursive functions of Japanese Personal Pronouns. Russian Journal of Linguistics, 21 (2), 305-319.

\section{Bio note:}

Etsuko Oishi. Dr, Professor at Tokyo University of Science, member of editorial board of Russian Journal of Linguistics. Research Interests: Pragmatics, Speech Act Theory, Discourse Analysis, Societal Pragmatics, English Language Education, Philosophy of Language. Contact information: e-mail: oishi@rs.tus.ac.jp

DOI: 10.22363/2312-9182-2017-21-2-305-319

\section{ДИСКУРСИВНЫЕ ФУНКЦИИ ЯПОНСКИХ ЛИЧНЫХ МЕСТОИМЕНИЙ}

\section{Етсуко Ойши}

Токийский исследовательский университет 1-3 Kagurazaka, 162-0825 Токио, Япония

Местоимение первого лица «я» относится к определенному индивидууму, выступающему в роли говорящего, в то время как местоимение второго лица «ты/вы» обращено к адресату сообщения. Однако этот общепринятый подход к личным местоимениям не позволяет в должной мере 
объяснить их функции в дискурсе, хотя только местоимения первого и второго лица относятся к т.н. «дискурсивным инстанциям» (instances de discourse, Benveniste). Цель статьи - показать, что местоимение первого лица «я» относится к говорящему как адресанту иллокутивного акта, а местоимение второго лица «ты/вы» — к слушателю как адресату иллокутивного акта. Такой подход проясняет дискурсивную функцию личных местоимений. Определение указательной функции личных местоимений позволяет последовательно анализировать японские личные местоимения и уровень формальности дискурса, представляющий определенную трудность для исследователей.

Ключевые слова: дискурс, личные местоимения, японский язык, речевой акт, speech acts, Дю. Л. Остин

\section{История статьи:}

Дата поступления в редакцию: 30 января 2017

Дата принятия к печати: 01 марта 2017

\section{Для цитирования:}

Oishi E. Discursive functions of Japanese Personal Pronouns // Вестник Российского университета дружбы народов. Серия: Лингвистика. 2017. Т. 21. № 2. С. 305-319.

\section{Сведения об авторе:}

Етсуко Ойши, доктор, профессор в Токийском исследовательском университете, член редколлегии журнала Вестник Российского университета дружбы народов. Серия: Лингистика. Сфера научных интересов: прагматика, теория речевого акта, дискурс-анализ, социальная прагматика, методика преподавания английского языка, философии языка. Контактная информачия: e-mail: oishi@rs.tus.ac.jp 